publication, and in putting calculations in order for that correction of coefficients ; and partly on three ramifications or supplements of the theory relating to the effect of the earth's oblate. ness, the effect of change of position of the ecliptic plane, and the effect of change of excentricity of the earth's orbit, and lunar acceleration. The last of these I have completed to my satisfaction, requiring only an examination of the external factor; the two others are progressing. The Admiralty have assisted me, on estimates, with a moderate grant (of amount named by myself), but much of the expense has been private."

The Report concludes as follows:- "After the details into which I have entered as applying to the present state of the Observatory, and after the remarks whici I have made in the two reports last preceding on the question of reduction of printing (which at some fitting time I would willingly again present to the consideration of the Visitors), and the note in the last report on the increase of annual expense, I have only to place before the Visitors, but for no immediate expression of opinion, the impression which frequently weighs upon me as to the ulterior organisation of the Observatory. The determination of places of stars, sun, moon, and planets, was handed down to me from my predecessors; it has in various ways been much extended. The magnetic and meteorological observations (the first originating with myself, the second partly with the movement introduced by the Royal Society and partly by myself) constituted a distinct branch of science, having this property in common with the original astronomical work, that it is incessant and regular. The much later introduction of photographic and spectroscopic astronomy, established at the instance of the Board of Visitors, and carried on with vigour and regularity, has created a third department. All these departments appear at present to be working efficiently and well. But I can easily imagine circumstances which would interfere materially with the successful continuation in one place of this triplicate series of observations. Though I think this possibility of partial failure worthy the contemplation of the Visitors, yet I do not see any necessity for action of any kind at the present time."

\section{INTERCOLONIAL METEOROLOGICAL CONFERENCE AT SYDNEY}

A METEOROLOGICAL Conference was held at Sydney in November last, the representatives of the different Colonies being Messrs. James Hector for New Zealand, Charles Todd for South Australia, R. L. J. Ellery for Victoria, and H. C. Russell for New South Wales, the last-named gentleman being chairman. The most cordial unanimity characterised the meeting, which lasted from the IIth to the $\mathrm{r} 4 \mathrm{th}$ of the montb, and the resolutions arrived at with a view to secure united action in their meterrological investigations and uniformity in the methods and times of observing and forms of publication augur well for the future of meteorology in the Australian Colonies. The whole question of weather telegrams was under anxious consideration. The system in present operation embraces only the Colonies of South Australia, Victoria, New South Wales, and Queensland, but a resolution was passed declaring it desirable to secure the co-operation of the Governments of Western Australia, Tasmania, and New Zealand in the system of inter-colonial weather telegrams. The facts pointed out by Mr. Todd as to the great regularity observed by the atmospheric disturbances in pursuing a course from west to east, and the statement by Dr. Hector that early notices could be sent from Queensland of the origin and progress of the dangerous and suddenly occurring cyclones that cross the northern part of New Zealand, sufficiently attest the practicability of the system of weather warnings and their practical value. For instance, the "great storm which wrecked the Dandenong in September, 1876 , could have been telegraphed in sufficient time to have prevented the great loss of property which took place at the different ports along the coast of New South Wales. We have the greatest pleasure in noting a deliverance by the Conference to the effect that weather telegrams and forecasts shall in all cases depend upon the observations used for general meteorological and climatological statistics. Much emphasis was laid on the establishment of high-level stations with a more special view to the investigation of the winds; and the Conference recommended that there be established in each of the Colonies, upon a high mountain peak, a meteorological observatory for the special study of winds and other meteorological phenomena, the most desirable positions being Mount Lofty, in South Australia, 2,500 feet high ; Kian- dra, in New South Wales, 4,60o feet; Mount Wellington, in Tasmania, 4,000 feet; Mount Macedon, in Victoria, 3,500 feet; and in New Zealand, Tauhara Taupo, 4,600 feet, and Mount Herbert, 4,000 feet. We hope that the Governments of the different Colonies will vote the small sums which are required to carry out the resolutions of the Conference, the giving practical effect to which will certainly confer substantial advantages on commercial, shipping, and other interests, and contribute materially to a more satisfactory development of the meteorology of this important part of the globe.

\section{UNIVERSITY AND EDUCATIONAL INTELLIGENCE}

Cambridge.-At St. John's College Prof. Liveing has been elected to a foundation fellowship, and Dr. Kennedy, Prof, Sylvester, F.R.S., and Prof. Churchill Babington were elected honorary fellows of the society.

The following awards for proficiency in natural science have been made at St. John's College :-A Foundation Scholarship to Samways; a Proper Sizarship to Love, and Exhibitions to Hart (already scholar), Weldon, Edmunds, Love, T. Roberts. Fleming was awarded one of the Hughes Prizes, given to the two most distinguished third-year students in any branch of study, and a Wright's Prize, with augmentation of the year's emoluments to rool. The Open Exhibition was awarded at Easter to Scott-Taylor (City Middle-class School, Cowper Street), and a second Exhibition to Clementson (Newcastleunder-Iyme).

We understand that Mr. W. J. Lewis has been appointed to perform the duties of Professor of Mineralogy at Cambridge until the close of the year, the period to which the election to the chair has been postponed by the University Commissioners.

\section{SCIENTIFIC SERIALS}

Zeitschrift fïr wissenschaflliche Zoologie, May.-Prof. Zygmunt Kahane, on the anatomy of Tenia perfoliata, Göze, as a contribution to the lnowledge of the Cestoids, with a plate and a woodcut. The actual facts recorded in the paper were originally laid before the Academy of Sciences of Krakau in May, 1878, and were afterwards published in a somewhat altered form, in the Polish tongue, in their Proceedings. The investigations were carried on during the summer and autumn of 1877 in the Zoological Institute at Leipzig, under the supervision of Prof. Leuckart. The history of the species is treated at length, and the paper extends over seventy-seven pages.--Dr. G. Haller, Contribution to a knowledge of the Tyroglyphida and their allies, with three plates : describes a new species of Listrophorus (L. pagenstecheri): On the genus Homopus, Koch. It is not an independent genus, but the forms are only the larval stages of Dermacarus, which is described as a new parasitic genus; Ty'ogly. phus megninii is described as a new species. There is a sketch of a delineation of the internal anatomy of Tyroglyphus and Dermacarus, and of the egg in these genera.-Prof. Ludwig Stieda, on the structure and development of the Bursa fabricii, with five woodcuts.--Dr. Hubert Ludwig, on the primary sand canal in the Crinoids, with some remarks on the comparative anatomy of the Echinoderms in general, with two plates.-Dr. H. Ludwig, new contributions to the anatomy of the Ophiuroids, with three plates.

Fournal de Physique, May.-Measurement of the electromotive forces of batteries and electromotive forces of contact of metals, by M. Pellat.-Study of polariser-prisms used in photometric observations, by $M$. Crova,-On the illumination of electrodes, by M. Colley.-On a new capillary electrometer, by M. Debrun. - To determine with the aid of an articulated system the conjugate points of an optical system, by M. Elie.

Archives des Sciences Physiques et Naturelles, May 15.-On the earths of samarskite, by M. Marignac.-Researches on the condensation of gases on the surface of glass, by M. Chappuis. - The Siemens machine and its application to transmission of force, by $M$. Achard.-Specific heat, latent heat of fusion, and point of fusion of various refractory metals, by M. Violle.

The Reale Istituto Lombardo di Scienze e Lettere, Rendiconti, vol. xiii., fasc. iv, and v.-The phylloxera considered in rural economy, by S. Cantoni.-Geological notes on the basin of Lake d'Orta, by Dr. Parona.--Iealth and beneficence; their mutual relations, byDr. Zucchi. 